\title{
鼻内視鏡手術の Pitfall
}

\author{
春名 眞一
}

獨協医大耳鼻咽喉・頭頸部外科

慢性副鼻腔炎における鼻内視鏡手術は，現在，世界的な標準術式になっている。種々の視野角の内 視鏡を用いることで，各副鼻腔を死角なく観察でき，的確な処置も可能になっている。一方，内視鏡 が導入されて手術の副損傷が減少したとの報告はない。かえって，内視鏡下に見やすくなり，安易な 手術操作が加わりやすくなっているとも感じる。Pitfall に陥りやすい主な原因を挙げると

1）内視鏡画面が平面で術野が広角で立体感がなく解剖を把握できにくい,

2）従来の手術同様に片手操作であり，術野が出血を伴うと手術操作がスムーズに抗こなえない,

3 ）斜視内視鏡操作や種々の鉗子操作に不慣れなことである。このような欠点を補うために手術支援 機器が開発されてきた。片手操作で吸引と鉗子操作ができるシェーバーシステムは手術操作をスムー ズにし, 多くの施設で導入されている。また, ナビゲーションシステムも保険適応され, 平面画像で の複雑な解剖の理解を容易にさせている。また, 術野の出血を抑えるために, 術前に抗菌薬やステロ イド薬を投与して炎症を抑え, 術中での局所麻酔の徹底や全身麻酔では麻酔科に最高血圧をできるだ け $100 \mathrm{mmHg}$ 以下に維持してもらうょうに指示している。しかしながら, 逆に強力なパワーをもつシ エーバーシステムは骨の削開も可能になり, 鉗子操作に比べて重大な副損傷を引き起こす危険性を秘 めている。またナビゲーションシステムには必ず誤差が生じ完全に信頼はできず，あくまで支援機器 であることを認識すべきである。最近では，局所解剖の変貌した再手術例の増加が指摘されており， また腫瘍や外傷への内視鏡手術の拡大適応も報告され，手術の難易度は増している。あくまで，基本 は鼻副鼻膑の解剖を内視鏡的視野で十分に理解し適切な針子操作を学ぶことである。発表では Pitfall に陥らないための基本的な手術操作と解剖の変貌した再手術例をビデオにて供覧する。 